\title{
Simulation Modeling of an Enhanced Low-Emission Swirl-Cascade Burner
}

SEMI-ANNUAL TECHNICAL PROGRESS REPORT

10/01/2002 through 3/31/2003

Dr. Ala Qubbaj, Mechanical Engineering Department

April 2003

DE-FG2602NT41682

University of Texas pan American

1201 West University Drive

Edinburg, Texas 78539-2999 


\section{DISCLAIMER NOTICE}

This report was prepared as an account of work sponsored by an agency of the United States Government. Neither the United States Government nor any agency thereof, or any of their employees, makes any warranty, express or implied, or assumes any legal liability or responsibility of the accuracy, completeness, or usefulness of any information, apparatus, product, or process disclosed, or represents that its use would not infringe privately owned rights. Reference herein to any specific commercial product, process, or service by trade name, trademark, manufacturer, or otherwise does not necessarily constitute or imply its endorsement, recommendation, or favoring by the United States Government or ant agency thereof. The views and opinions of authors expressed herein

do not necessarily states or reflect those of the United States Government or ant agency thereof. 


\begin{abstract}
The research team was formed. The advanced CFDRC-CHEMKIN software package was installed on a SUN-SPARC dual processor workstation. The literature pertinent to the project was collected. The physical model was set and all parameters and variables were identified. Based on the physical model, the geometric modeling and grid generation processes were performed using the CFD-GEOM (Interactive Geometric Modeling and Grid Generation software). A total number of 11160 cells $(248 \times 45)$ were generated to numerically model the baseline, cascaded, swirling, and swirling-cascaded flames. With the cascade being added to the jet, the geometric complexity of the problem increased; which required multi-domain structured grid systems to be connected and matched on the boundaries.
\end{abstract}




\section{Table of Contents}

I. Title Page

II. Disclaimer Notice

III. Abstract

IV. Table of Contents
A. Experimental (physical) model
B. Geometric Modeling and grid generation
C. Results and Discussion (Pending)
D. Conclusion (Pending)
E. References (Not available) 


\section{A. EXPERIMENTAL (PHYSICAL) MODEL}

Figure 1(a) shows the actual physical model, which consists mainly of a combustion chamber made from steel, $63.5 \mathrm{~cm}$ x $63.5 \mathrm{~cm}$ cross-section and $139.7 \mathrm{~cm}$ height. The chamber is provided with air-cooled Pyrex windows of dimensions $38.1 \mathrm{~cm}$ x $114.3 \mathrm{~cm}$ on all four sidewalls. The top of the chamber is connected to the atmosphere through an exhaust duct (as seen in Fig. 1). The fuel and oxidant are introduced to the combustion chamber through separate streams in a non-premixed or diffusion combustion process. The fuel is introduced through a stainless steel burner, of internal diameter $3.2 \mathrm{~mm}$, inserted in the centerline of the chamber, and the air is introduced through an annular inlet of diameter $0.2 \mathrm{~m}$, surrounding the fuel burner as depicted in Figure 1. Swirl is imparted to the air stream at swirl number (SN) of 1. The swirl number represents the ratio between the angular and axial air velocities. The cascade consists of a set of four identical venturis, with circular arc profiles, to form a cascade. The dimensions of the venturis are given in table 1 and shown in Fig. 1. The simplified physical model used in the computations, assuming axisymmetric flow conditions, is provided in Fig. 2. The operating and boundary conditions are given in Table 1.

\section{B. GEOMETRIC MODELING AND GRID GENERATION}

The computational domain encompassed half of the flame jet assuming axisymmetric flow conditions (as seen in Fig. 2) and extended to $139.7 \mathrm{~cm}$ in the axial direction and $31.75 \mathrm{~cm}$ in the radial direction. The grid cells were generated with increasing spacing in the radial and axial directions; this provided an adequate resolution where gradients were large, i.e., near the centerline, and saved CPU time where gradients were small, near the edges (as seen in Fig.3)

The venturis were modeled as two-dimensional axisymmetric convergent nozzles around the jet. With the cascade being added to the jet, the geometric complexity of the problem increased; which required multi-domain structured grid systems to be connected and matched on the boundaries. The CFD-GEOM module (Interactive Geometric Modeling and Grid Generation Software) in the CFD-ACE+ package was used for geometric modeling and grid generation purposes. 


\section{RESULTS (pending)}

The physical model was set, the geometric modeling and the grid generation processes were performed for the baseline, cascaded, air-swirling, and swirling-cascaded flames. Therefore, the numerical computations are about to start. The results are expected to be available soon.

\section{CONCLUSION (pending)}

As soon as the data become available, the conclusions will be made.

\section{E. REFERENCES}

Not available

Table 1: Operating and Boundary Conditions

\begin{tabular}{ll}
\hline Fuel & Natural Gas $(95 \%+)$ \\
Burner diameter $\left(\mathrm{d}_{\mathrm{b}}\right)$ & $3.175 \mathrm{~mm}$ \\
Jet-exit Reynolds number & 9000 \\
Jet-exit/ Fuel axial velocity $\mathrm{u}_{\mathrm{x}}$ & $46.65 \mathrm{~m} / \mathrm{s}$ \\
Venturi throat diameter $(\mathrm{d})$ & $0.0625 \mathrm{~m}$ \\
Venturi diameter ratio $(\mathrm{D} / \mathrm{d})$ & 1.25 \\
Angular air velocities $\mathrm{u}_{\theta}$ & $3 \mathrm{~m} / \mathrm{s}$ \\
Axial air velocity $\mathrm{u}_{\mathrm{x}}$ & $0.3 \mathrm{~m} / \mathrm{s}$ \\
Swirl number (rw/U) & 1.0 \\
Near-burner axial location: x/d & 4.63 \\
& $295 \mathrm{~K}$ \\
Ambient temperature & $100 \mathrm{kPa}$ \\
Ambient pressure &
\end{tabular}



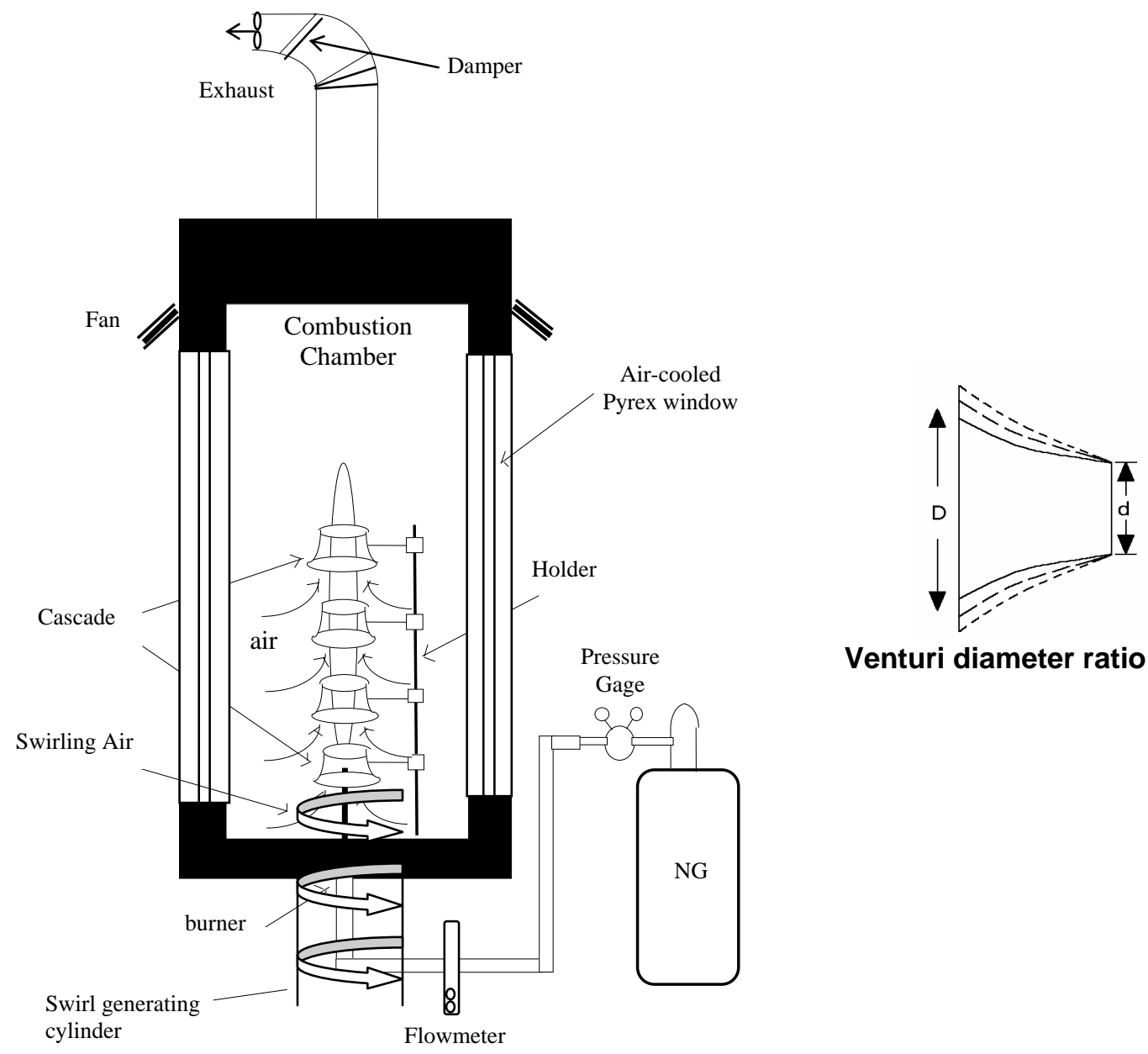

Venturi diameter ratio (D/d)

Figure1: Actual physical model 


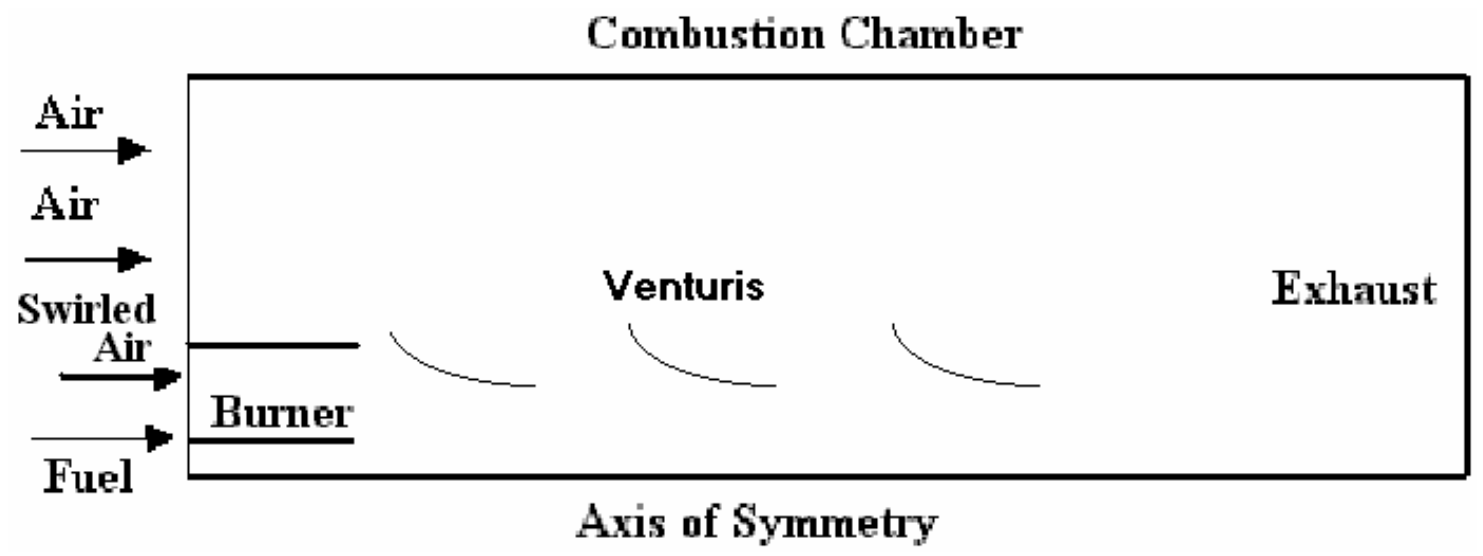

Figure2: Simplified Problem geometry 


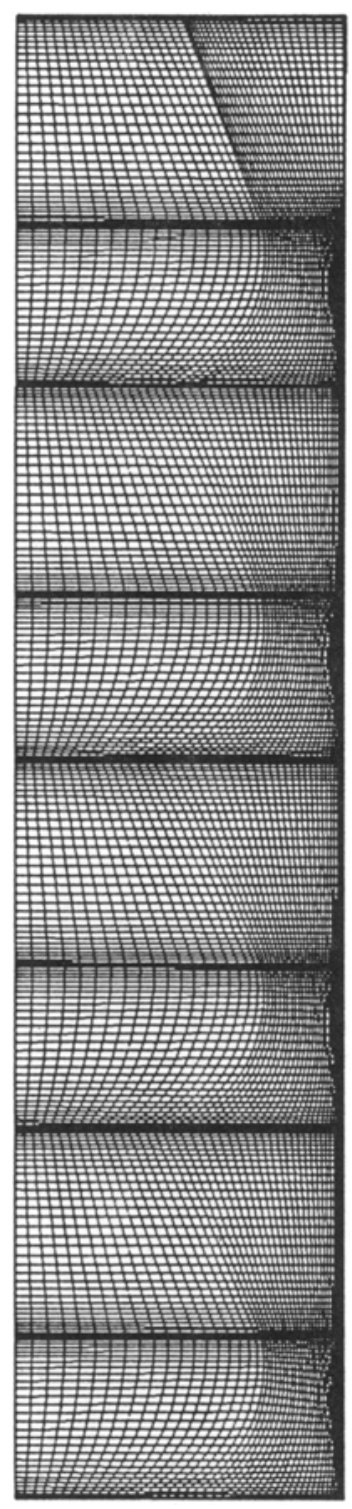

Figure 3: Non-uniform grid generated for flow computations 